Article

\title{
Community Development through Supply Chain Responsibility: A Case Study of Rice Supply Chains and Connected Rural Communities in Central China
}

\author{
Li Liu 1,2,*D, Helen Ross ${ }^{2}\left(\mathbb{D}\right.$ and Anoma Ariyawardana ${ }^{2} \mathbb{D}$ \\ 1 Institute for Advanced Study in Social Sciences, Fudan University, Shanghai 200433, China \\ 2 School of Agricultural and Food Sciences, The University of Queensland, Gatton, QLD 4343, Australia; \\ helen.ross@uq.edu.au (H.R.); a.ariyawardana@uq.edu.au (A.A.) \\ * Correspondence: liuli@fudan.edu.cn or li.liu1@uqconnect.edu.au
}

Received: 4 December 2019; Accepted: 23 January 2020; Published: 27 January 2020

\begin{abstract}
Supply chains depend on community resources such as entrepreneurs, natural resources, and facilities in value creation and successful operation, while communities need development opportunities from supply chains to build and maintain prosperity. The mutual influence between supply chains and communities offers opportunities to integrate sustainability initiatives into the chain. The concept of supply chain responsibility (SCR) represents a new philosophy that helps create value for communities, but so far does not link well with the idea of community and is viewed one chain at a time. A more integrated and holistic consideration of supply chain-community interactions incorporating multiple supply chains and communities adds to the perspective of community development through SCR. It not only leverages community development as a significant level of analysis in supply chains, but also considers all chains that interact with a community. We use a case study in China's rice industry to examine the complex and multifaceted supply chain-community interactions in a network of three types of rice supply chain and two rural communities, to understand the theoretical and practical potential in an enriched conceptualization of SCR. The interactions among the supply chains and communities provide significant insights into how to create sustainability for both.
\end{abstract}

Keywords: supply chain responsibility; community development; sustainability capabilities; rice industry; China

\section{Introduction}

Supply chains (SCs) depend on community resources such as entrepreneurs, natural resources, and facilities in value creation and successful operation, while communities need development opportunities from SCs to build and maintain prosperity [1]. The mutual influence between SCs and communities offers opportunities to integrate sustainability initiatives into the chain [2-4]. This concept, supply chain responsibility (SCR), represents a new philosophy that helps create value for communities $[5,6]$. SCR examines the long-term orientation of interactional relationships among SCs and communities in a dynamic and integrated manner, rather than focusing on short-term SC outcomes within a community.

In current research, SCR conceptualizes relationships and interactions between SCs and social wellbeing (such as rural community development) [7]. Porter and Kramer argue that agribusinesses and agri-food SCs' involvement in disadvantaged producers and rural communities' development helps to maintain their reputations, create new opportunities, and build a viable business environment [8]. These interconnections lead to the growing concerns that agri-food SCs not only take initiatives to 
improve the value derived from agricultural products [5,9], but also have the responsibility to promote functional communities or community sustainability proactively $[10,11]$.

Despite the attractiveness of the idea of SCR, the actual ways SCR-related processes and practices work in communities [12], and what types of SCR are connected with community development [10], remain barely known. The existing view of SCR as focused on a single agri-food or agribusiness chain treats rural communities as symbols of the changes in the chain [8], without being focused on the purposes of the development that the policies, models, and activities in agri-food SCs aim at delivering. This perspective has shortcomings with respect to the complexities in the interactions among agri-food SCs and rural communities.

Firstly, the oversimplified view of SC, related to product-related networks and activities, is inadequate to conceptualize the social structure and boundaries of SCs [13]. Donovan and Poole indicate that some research, lacking a deeper view of the social structure of agri-food SCs, uses the variations in SC operations and processes to explain community development outcomes [14]. The researchers may wrongly attribute positive community changes to interventions in agri-food SCs, while negative changes may be attributed to the external environment.

Secondly, the literature on agri-food SCs' development and their impacts on rural communities has stressed the power of business policies, models, and activities to affect rural change dynamics-a one-way perspective [14-16]. The various frameworks fail to consider community agency and potential, even if they accept that community institutions are a partial driver of change in agri-food SCs [17]. The lack of community analysis reproduces frameworks to balance the conflicts between chains and communities, without raising the awareness of reciprocal community effects on agri-food SCs' development.

Thirdly, the existing research relies on a static view of SC-community interactions. It ignores the dynamism in networks of explicit and implicit interconnections of actors, and the chains that interact with each community, to influence community development [18]. It also does not consider how the social structure and agency of rural communities continuously evolve with agri-food SCs' impacts, and how communities influence the form and direction of chain development. In general, researchers treat the multiple ways in which agri-food SCs influence community development as emanating from outside the community, not an implicit part of the community's dynamics [10,14]. Hence, existing research has not addressed the context of nor the potential in the SCR concept adequately. A deeper, integrated, and dynamic perspective of agri-food SCs-community development interactions is needed to improve conceptualization of SCR $[14,16]$.

Moving beyond the narrow view of SCR as the action of an individual chain on a community, this paper explores an alternative view of SCR that is integrated within a network of chains and villages which are connected via their dynamic interactions. Such an orientation of SCR in a network is aligned with the viewpoint that the responsibility for rural community development is shared by the government, villages and diverse connected agri-food SCs in China [19]. This suggests that individual chains in favor of creating responsible social outcomes have to consider themselves as contributing within a network of actors with shared responsibility. This paper seeks a holistic understanding of the current interactional patterns and effects between agri-food SCs and community development. Rather than achieving desired outcomes in every respect, the interactions between them may be either inhibited or encouraged by various factors. A deeper understanding of the interactions can provide insights into the alignments or misalignments between intentions and real achievements [5]. Specifically, the interactions within a network of agri-food SCs and communities in rural China are explored through three research questions: (1) What are the current contributions of SCs to community sustainability? (2) What levels of community sustainability are connected with the different contributions of SCs? (3) How do SCs contribute to community sustainability, especially what aspects or elements of SCs contribute to community sustainability? These evaluations of SC-community interactions help identify SCR pathways for community sustainability. 
The paper has seven sections. Following the introduction, Section 2 explains SCs, communities, SCR, and then links SCR to the concept of a network of agri-food SCs and rural communities. Section 3 introduces the context of the case study, i.e., governance of the rice industry in China. Section 4 describes the research design and methodology of this study. Section 5 presents the results concerning community capitals in villages, chain level sustainability capabilities, and rural communities' interactions with different types of rice SC. Section 6 discusses these findings from a community and a SC perspective, and suggests directions for future research. Section 7 draws conclusions from the research.

\section{SCR in Supply Chain Networks}

SCR offers opportunities to bring together different stakeholders, so that their connections can lead to innovation in the thinking and practices among chain actors and community members. Drawing on the existing literature, this section conceptualizes SCR in terms of a network of agri-food SCs and rural communities rather than single chains, i.e., SC networks.

\subsection{Supply Chain Analysis}

In order to conceptualize SCs further, Carter et al. [13] propose that the theory of SC needs to involve all actors and complex scenarios related to the chain, to recognize a dimension of a "support SC": An invisible social structure of actors within which an individual SC is embedded and shaped. Actors, organizations, and chains in the context of agricultural industry do not exist in isolation: They are interconnected and form a complex adaptive system [13]. Consistent with this view, we propose that the complexities of SCs can be understood through combining three forms of analysis: (1) The multiplicity of chain actors; (2) the attributes of each SC; (3) different life-cycle or evolution phases of $\mathrm{SCs}$ in various regions. The combined perspective provides a view of the embeddedness of actors and the whole chains in these social contexts. In other words, this perspective recognizes that the SCs are embedded in broad social structures and institutional issues, which helps to generate practical knowledge to investigate the complexity in SCs and those related sustainability issues. This approach contrasts with the majority of SC studies, which consider a single chain [6] or compare chains from different industries $[2,20]$.

\subsection{Community Capitals}

Every community has some resources in it, and when these resources are invested to create new resources, they become a form of "capital" in the community [21]. Community capitals provide a holistic, dynamic, and integrated way of considering the attributes of communities and ways they change. Various types of "capital" are seen as interdependent, interactive, and synergistic with resources, and the stocks and flows of capital assets affect a community's prosperity [22,23]. Further, capitals, or social structures and resource allocation mechanisms in the communities, are open and ready for alteration [24].

The idea of community capital is connected with Sen's capability approach [21], which stresses creating an empowering structure with freedom of choice to spur people's "capacity for change" $[25,26]$. The concept of capacity refers to three combined elements: Resources, cognitions, and institutions [27]. Community members use the capitals and their capabilities to achieve goals. The constant changes in community capitals, as they interact, are shaped by, and reshape, the community structure. The evolution of the community structure, through collective agency and actions among a network of actors, is a way towards community development [28,29].

\subsection{Supply Chain Responsibility}

In the context of interaction of agri-food SCs and rural communities, we define supply chain responsibility (SCR) as "the collective consideration of, and response to, issues beyond the narrow economic, technical and legal requirements of the supply chain to create a rewarding system that links SC goals such as profits to community sustainability gains, enhancing economic value by creating 
social and environmental benefits for the community", adapted from ([6], pp. 291-292). This definition offers a community-oriented understanding of SCR. Community-oriented here refers to dynamic processes aiming at creating mutual supportive interactions between the agri-food SCs and the rural communities they work in and with. In other words, a SCR perspective encourages the development of rural communities and agri-food SCs together. It represents more than standard chain level initiatives, policies, and development projects to create economic interests [6,30]. The interactions among SCs and communities also offer a lens to tackle the issues of power and conflicts, to benefit agri-food SCs and rural communities together within their overall political, institutional, and market context.

Community-oriented SCR brings SCs and communities (or networks of communities) together to create collective opportunities and benefits, including developing community capitals and production capacity at chain level, adaptive capability, and innovative capability (i.e., sustainability capabilities) [31]. These interactions are affected by individual, household, community, industry, and regional contexts and initiatives. The capability approach stresses that chain actors are active agents with valuable resources to shape institutional conditions [32]. A community-oriented SCR approach would tackle inclusiveness in the development of SCs, as the less developed communities and chains could gain equal consideration in a combined system context.

Meanwhile, the network concept provides additional concepts and tools to take collective initiatives into account [33]. The actors within a network or with connections can draw on the concept of community, considered in terms of emergent and dynamic collective groups, to organize their interactions [34]. As community members have always been engaged in interactions within and beyond their rural settlements, the broader relationships of these community actors in such a network, offering them the access to complementary resources, are significant for developing their capabilities. Choi and Kim indicate that consciousness of social capital, via network, in a SC can alter and enrich a SC option [35]. Investments in network-wide awareness and efforts contribute to a boundary-spanning community structure that can involve all of the "capitals". Additionally, the SC focus shifts from a narrow structure of distribution of product to focus on the agri-food SCs-rural communities nexus.

\section{Rice in China}

The SC-rural community interactions always occur in a specific context. The rice industry in China, representing a specific context of the interactions for rice SCs and rural communities, is chosen for analysis in this study. Rice is a staple food for more than $65 \%$ of the Chinese people. The Chinese central government plays a leadership role to ensure development of capabilities in rice farming villages and rice SCs [36]. Through various projects, the central government tackles challenges in the rice industry related to agro-environmental degradation, food safety issues, inadequate agricultural facilities (causing droughts and floods), and low profit margin (caused by low levels of technology and market certification).

\section{Governance: Government Intervention Adding Some Free Market}

A contract farming-like mechanism is used in the rice industry to ensure small farmers' livelihoods in rice farming and coordinate operations in rice SCs. Sino-grain (China Grains Reserves Corporation-a state-owned enterprise) serves to set a minimum rice price and provide small farmers with access to the market. Sino-grain's strategic economic and social functions are achieved in two ways. It acts as an agent to secure a minimum procurement price for farmers in the rice market through its 31 branches. In doing so, through a top-down governance structure, it acts to reduce impacts from the global rice market. Sino-grain also adjusts the paddy rice (the individual rice kernels that are in their natural, unprocessed state) supply and demand in the rice market to reduce random variability in quality and volumes, and to stabilize the rice price. According to Chinese policy, when the price of grain is low, Sino-grain should buy it for more than the market price, to profit the farmers. When the price is high, Sino-grain should sell it at the average price, lower than the market price, to benefit the consumers. Sino-grain also coordinates the process of paddy rice storage. Its stored rice stocks are rotated every 
two years because rice is perishable, and continued rotation of stock reduces potential storage losses from pest infestation or moisture damage.

\section{Methodology}

This research adopts the case study method [37] to examine the dynamics and processes for sustainability in a network of SCs and communities. Wuhan, the capital city of Hubei Province, is chosen as the main study area (Figure 1). It is located in central China $\left(30^{\circ} \mathrm{N} 115^{\circ} \mathrm{E}\right)$, which is dominated by a humid sub-tropical monsoon climate with total annual rainfall average between 1150 and $1450 \mathrm{~mm}$ per year. Wuhan has thirteen districts, covering 8569 square kilometers. Among these, seven districts in the center of the region are urban areas, and the other six districts in the peri-urban area are mainly rural areas devoted to farming. As the whole region of Wuhan is relatively flat plain, and approximately a quarter of the area is constituted by water and lakes, it is one of the key agri-food production areas in China, referred to as the "bowl of rice and fish". The agricultural industry in Wuhan's rural areas has moved towards upgrading the rice industry, along with the horticulture, fishery, and agro-tourism industries. Because of its key role in agricultural production in China's domestic market, the public and the private sectors are both involved in strategies that address sustainability challenges regarding economic development, social equity, and agro-environment issues.

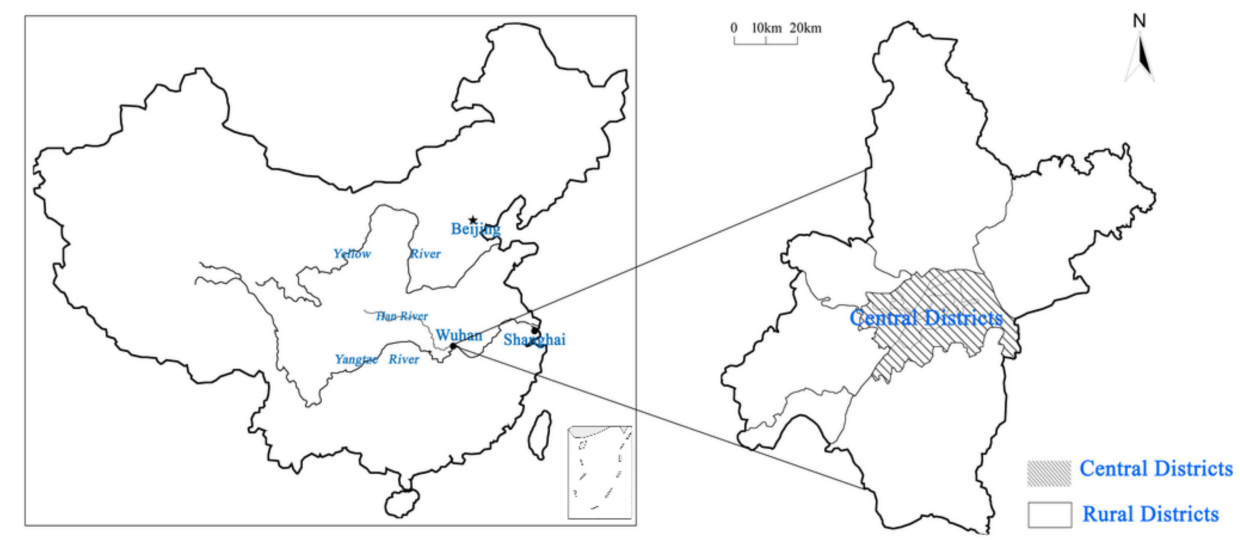

Figure 1. Location of the Study Area-Wuhan, Central China.

\subsection{Scoping}

SCR in the rice industry encourages interactions among diverse chains and villages, and a holistic view of the network of chains and villages helps to identify opportunities to benefit the network as a whole. The SC network is a collection of the units of analysis (chains and the interconnected villages) that potentially interact as a system. This study adopted the walking-the-chain observation and interview approach to select the most "typical" rice SCs and villages. The walking-the-chain approach is a rapid SC appraisal [38]. In this approach, the researchers quickly scope the performance of the whole SC in sufficient detail by visiting and collecting data from each participant in the chain. This ensures that subsequent activities are focused on the critical elements of the research problem. The core methods include key informant interviews, structured direct observations, focus group interviews, community interviews, and informal surveys. In this study, semi-structured and open-ended interviews and observation were used to understand the rice sector in Wuhan, especially mapping important chain processes, SC structures, and coordination mechanisms.

\subsection{Data Collection: Villages}

This study chose two rice farming dependent communities ( $\mathrm{QF}$ and $\mathrm{XH}$ villages) with different levels of economic development. QF village is well developed in terms of the collective income per 
year and modern infrastructure, while $\mathrm{XH}$ village has little collective income per year or modern infrastructure. The data on community capital assets affected by the rice SCs was collected through in-depth interviews with the village leaders, community members, and other stakeholders $(n=5$ in $\mathrm{QF}$ village, $n=4$ in $\mathrm{XH}$ village). The questions explored three issues: (1) The status and evolution of community capital assets; (2) the processes of rice industry development in their villages; and (3) visions for village development. Then, household semi-structured interviews were used to understand household level capital assets and their engagement in rice SCs. Households were reached by door knocking in the whole village, and we interviewed the couple in rice growing households only. Altogether, 52 household interviews were conducted in the two villages ( $n=25$ in QF village, $n=27$ in $\mathrm{XH}$ village).

\subsection{Data Collection: Rice Supply Chains}

Paddy rice is a relatively low-value crop, and mills managed by farmers, co-ops, and small to medium enterprises (SME), though with different scales of processing and marketing, add value to the paddy rice. The different scales of rice mills give form to farmer-led, co-op-led, and SME-led rice SCs. Sustainability capabilities in the three types of rice SC were investigated through in-depth interviews with key informants in the chains $n=26$ ). These informants included main actors-farmers in the villages, brokers (or collectors), wholesalers, retailers, and consumers-and supporting actors-government officers, extension service providers, and input suppliers. The snowball sampling strategy was used to select the respondents, beginning with a government officer, who made initial referrals to key actors in each type of chain during the mapping of the chains. Subsequently, those actors were asked to suggest others who were involved at the different stages in their own and other chains. The questions involved (1) individual actors' sustainability capabilities [39]; (2) the structure of the rice SCs, such as product flow, information flow, financial flows, and relationships; and (3) the evolution of the rice SCs over time and space. Meanwhile, four focus group discussions were employed among selected actors across various rice SCs and connected $\mathrm{XH}$ and QF villages. One group (5 participants) consisted of rice growers that were associated with various types of rice SC. Another group (6 participants) consisted of rice brokers and co-op members. These two groups were mainly male. There were two groups ( 7 participants) for female villagers, one in each village. The focus group discussions aimed at enriching and validating the information from the in-depth interviews, and providing reflections on sustainability capability building in the three types of SC. The data on both villages and chains was collected from 1 March 2015 to 3 July 2015.

\subsection{Data Analysis}

QSR NVivo 10 software was used to help code, organize, and sort information. First, open coding allowed emergent meanings and structure to arise from the data on both capital assets and SCs. After the open coding, we made connections between categories, based on themes and descriptions. According to emerging themes, an initial version of the case report was written. Based on this, a later stage of coding and analysis focused on the interactions between community capital assets and chain level sustainability capabilities. The re-conceptualization processes informed understanding of the underlying social structure in the network of rice SCs and rice villages, such as migrant workers in the village and the effects of globalization processes at the local level. Based on the multiple rice SC-rural communities' interactions, we wrote the second version of the case report, as reported here.

This study used three ways to increase validity, i.e., the trustworthiness and rigor of research. Firstly, key results were cross-verified by multiple sources of evidence (triangulation). For instance, the household interviews were used to verify the data from in-depth interviews with village key informants. This helped to reduce the possible bias in viewpoints on the community capital assets caused by different power positions in the village. The main chain actors were asked to nominate one or more other people to provide complementary information. The combination of information from complementary respondents provided checks between what was said by each. Meanwhile, the 
ethics process (ethics approval was granted by The University of Queensland, Australia), guaranteeing anonymity, helped to avoid biasing responses towards what respondents might think desirable to say. Furthermore, the interviews not only focused on describing activities, capabilities, and performance, but also asked a set of questions to justify an action, giving reasons, support a claim, or make a causal statement. The rival explanations and possibilities were considered to increase internal validity.

\section{Results}

The attributes of the interconnected villages and chains documented from in-depth interviews with village leaders and chain actors are described in Table 1. Both QF and $\mathrm{XH}$ villages are located along the upstream of an irrigation system, Jinshui River, so they have adequate water supplies. They have been engaged in rice farming for more than a hundred years, and the rice crops in these and many other villages are supplied to three chain types-farmer-led, cooperative (co-op)-led, and SME-led rice SCs. Since the three chains operate in the same context-the same district and the same industry-they sometimes compete and sometimes cooperate in the processes of rice production, procurement, and processing. The following section presents the community capitals in $\mathrm{QF}$ and $\mathrm{XH}$ villages; the sustainability capabilities in farmer-led, co-op-led, and SME-led rice SCs; and their interactions.

Table 1. The Characteristics of Villages and Rice Chains in the Network.

\begin{tabular}{|c|c|c|c|c|}
\hline QF Village & XH Village & Farmer-Led Chains & Co-Op-Led Chains & SME-Led Chains \\
\hline $\begin{array}{l}\text { Population } \\
\text { 1000; Income: } \\
\text { 100,000RMB per year } \\
\text { from the transfer of } \\
\text { spare collective } \\
\text { farmland; }\end{array}$ & $\begin{array}{l}\text { Population } \\
\text { 2000; Income: no } \\
\text { alternative sources of } \\
\text { collective income; }\end{array}$ & $\begin{array}{l}\text { One farmer managed a whole } \\
\text { SC process from the } \\
\text { production to the processing, } \\
\text { and the marketing. } \\
\text { In another rice SC, some } \\
\text { brokers collected rice from } \\
\text { individual households and } \\
\text { supplied to mills and } \\
\text { Sino-grain. }\end{array}$ & $\begin{array}{l}\text { Co-op organizations } \\
\text { with moderate levels of } \\
\text { technology; } \\
\text { entrepreneurial } \\
\text { commitments from rural } \\
\text { elites and government } \\
\text { subsidies; }\end{array}$ & $\begin{array}{l}\text { Modern corporations } \\
\text { with advanced } \\
\text { technologies, own } \\
\text { brands and registered } \\
\text { trademarks; acquire rice } \\
\text { from a wide array of } \\
\text { sources, including } \\
\text { farmers, rice brokers, } \\
\text { and Sino-grain. }\end{array}$ \\
\hline
\end{tabular}

Note: RMB—Renminbi (Chinese currency).

\subsection{Community Capitals in QF and XH Villages}

The mapping of community capitals in the two villages showed the complexities of community capitals associated with the influence of rice SCs.

\subsubsection{Natural, Physical, and Financial Capitals}

The first observation was that the two villages, with the various levels of government department aid, clearly increased stocks across the natural, physical, and financial capitals to achieve sustainable conditions for rice production. In QF village, various government programs sought to reduce the level of pollution in the agro-environment, such as the excessive heavy metal in the soil, non-point source pollution, and water pollution within the village boundary. However, the level of pollution resulted from previous government decisions. In $\mathrm{XH}$ village, the village leader reported that the government had sought the protection of natural capital in Wuhan city by relocating a chemical factory from the inner city of Wuhan to the neighboring city, but it caused severe water pollution in the river upstream of the study area. In both villages, the government had routinely invested in public physical capital to reduce the level of deterioration in farming facilities. This was combined with other chain level institutional reforms, including abatement of agricultural taxes for all the farmers, subsidized rice farming, and minimum price for procurement rice, to increase farmers' income. Recently, new government projects-a rice co-op mill and agro-tourism-had been implemented to diversify household incomes and increase employment opportunities in QF village. Meanwhile, rice farming households created various production models, such as rice-lotus rotational farming, the innovative eco-agricultural system of mixed rice-shrimp agriculture, and expanding the scale of rice farming, to optimize human resources and land arrangements to expand economic benefits. 
A second observation that emerged from analyzing according to the community capitals was the importance of transforming community structure and agency into a "pro-change" asset. The government's building of infrastructure at the community level had a low level of genuine commitment among villagers. The government officer indicated that local farmers purposely distanced themselves or even disconnected from government officers in many government engagement projects. He explained that when the government came to supervise the work in the community, "arranged" farmer delegates would report desirable words or issues, rather than giving their real opinions. He also said that the missing voice of local farmers further strengthens the power of village leaders, as the village leaders could speak for their personal interests, not those of the households, when making the community "decisions". This was confirmed by the villagers. The distance between the government and most community members not only caused farmers' disinterest and inaction, and led to deterioration in farming facilities, but also led the communities to band together in passive resistance to the government in the processes of building community facilities. Similarly, the nature of the sources of financial capital has limited the prospects for economic development in the villages. Entrepreneurial programs were controlled by the community leader, such as a rice co-op mill in one village, were not organized well to yield collective economic benefits, or improve the uneven development among rural households. These programs also faced great natural shocks such as pest infestations and floods, and market risks. Some farmers criticized government subsidies to large-scale farmers, as the assumptions about economies of scale followed by government promoted large-scale farming, but led to lower yields per unit of area.

\subsubsection{Human, Social, Cultural, and Political Capitals}

The government and some community members use the human, social, cultural, and political capitals in strategies to build opportunities for development. The government officer indicated that a typical government intervention strategy was the recommendation of an assertive candidate for election as the village leader. He explained that a community leader with active development initiatives and entrepreneurial spirit can pursue close connections with external organizations.

The leader's strategic efforts were directed towards reducing the economic pressure on farmers and constructing financial capital in the village. The village leaders relied on their personal networks to secure government projects, and argued that effective leadership of the village committee entailed ability to engage with potential problem-solving networks. Especially, the village leaders are keen to accumulate political support relationships. In the process, social capital becomes political capital.

The villagers said that they maintained viable personal social networks with family members, friends, or relatives, which improved their livelihoods and abilities to cope with adversity (like food shortages, natural disasters, poverty). For instance, the elderly family members have the responsibility of taking care of their grandchildren and work on rice farming, while the younger couples work in the city in non-farming jobs. The household level division of labor encouraged development possibilities outside the rural area, and reduced costs in raising children. The rural families also adapted to the industrial development opportunities in the whole region, and they invested in personal assets for potential livelihood opportunities.

However, the extensive internal community linkages and external government connections involved in the social, cultural, and political capitals failed to contribute long-term household economic wellbeing or village improvement for three reasons. Firstly, some villagers reported that maintaining their personal social capital entailed spending money. The cost of special investments to support relationships became a significant economic burden for most low-income farmers. Secondly, the high dependence on external government resources and decision-making only improved the villages' short-term service provision, not sustainable resources. Thirdly, minds focused on development through external resources encouraged dependency and failed to encourage the building of community agency. The village leaders in both $\mathrm{QF}$ and $\mathrm{XH}$ village reported that the close interaction with governments through various programs gave the government a dominant role in decision making in community development projects. This hierarchical institutional process decreased community 
organization and autonomy in the implementation processes, such as communication among rural residents, the sense of responsibility, and joint endeavors in community affairs.

To build the synergy necessary for further community development, cultural and political capitals in the two villages needed to be reformed to foster a sense of agency within the community, and to reduce long-term conflict. Some villagers reported that many village members were concerned more with personal wealth creation and pleasure than collective achievements. But such individuals' proactive personal livelihood strategies were likely to be incompatible with government plans, and the unexpected external political and economic risks decreased the effectiveness in pursuing both individual and collective development opportunities. In contrast, the community organization and community leadership, through collective fish farming and the collaborative vegetable marketing activities in the past, increased collective welfare and promoted village economic development without much cost. Additionally, consensus on collective farmland redistribution used to be achieved through open communication (village meetings) and broad participation (including women and other stakeholders) among farmland holders and claimants, according to community norms and "village committee organizational laws" (procedures for decision making). Subsequently, the "official" certificates of land use rights issued by the government in the name of property regulation reforms could have added "legitimacy" to the collective farmland ownership and household land operation rights. However, it challenged the community-wide institutional order, and legislative rigidity led to the decay of the grassroots democracy involved in the collective decision-making process. Meanwhile, farmers had developed a stronger sense of their personal rights, and limited moral responsibility for making monetary or material contribution to community affairs.

Thus, the seven capitals in the two villages interacted in multi-faceted ways. Rice SCs created short-term changes in natural, physical, and financial capitals. These, however, had limited effects on rice farmers regarding profit and personal welfare. Meanwhile, the use of human, social, cultural, and political capitals promoted a community structure that is fragmented, with a focus on individual efforts at the expense of collective agency as existed in the past. The stocks of seven capitals in the two villages may further affect the sustainability capabilities of the three types of rice SCs, described in the next section.

\subsection{Sustainability Capabilities in Farmer-Led, Co-Op-Led, and SME-Led Rice Supply Chains}

The structures and coordination mechanisms of product flow of the rice SC network are mapped in Figure 2. The mills, led by farmers, community-based co-ops, and SMEs, procure the paddy rice from farmers in the two villages and from branches of Sino-grain, and then sell the processed rice to the customers along their chains. Among these chains, the smaller mills of co-ops and farmers mainly serve the needs of their neighbors, local schools, and restaurants, while the larger SMEs' mills supply rice to the wholesale and retailing markets within and beyond the local areas. In the rice network, there was a complementary type of farmer-led rice chain, where rice farmers also acted as brokers (or collectors) to procure and sell paddy rice to diversify their livelihoods. The network is summarized in Table 2. 


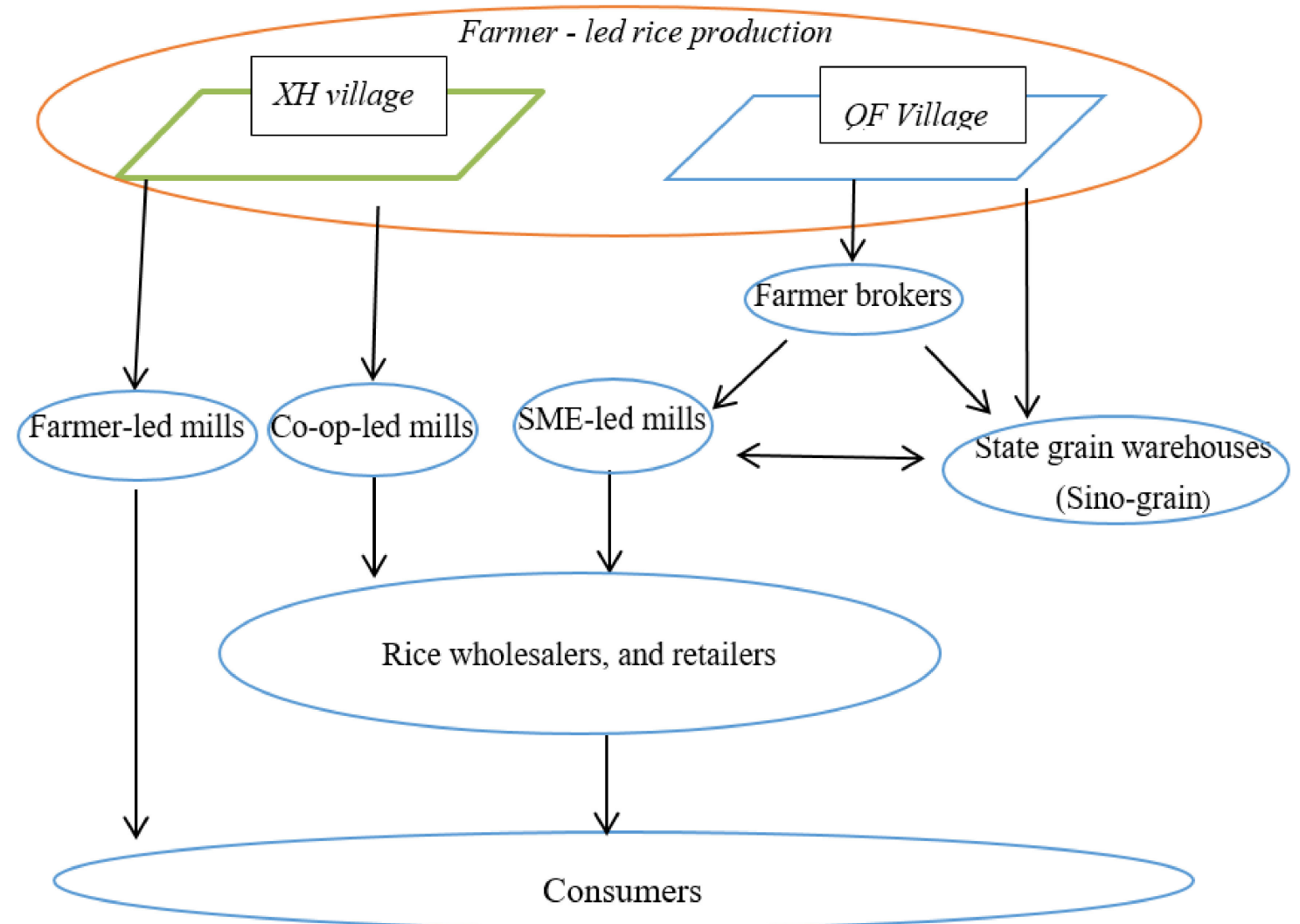

Figure 2. The Rice Supply Chain Network.

Table 2. Summary of Sustainability Capabilities in Farmer-led, Co-op-led, and SME-led Rice Supply Chains.

\begin{tabular}{|c|c|c|c|}
\hline & Farmer-Led Rice SCs & Co-Op-Led Rice SCs & SME-Led Rice SCs \\
\hline Social capabilities & $\begin{array}{l}\text { Trust and social capital and } \\
\text { the maintenance of food } \\
\text { nutrition; } \\
\text { Social exclusion resulting } \\
\text { from excessive government } \\
\text { interventions or villagers' } \\
\text { individualistic and } \\
\text { competitive behaviors; }\end{array}$ & $\begin{array}{c}\text { Low level entrepreneurial } \\
\text { commitments due to power } \\
\text { relations, low potentials to improve } \\
\text { rural livelihoods; } \\
\text { Potential social exclusion } \\
\text { (managerial capabilities, shortage of } \\
\text { financial capital, lack of supportive } \\
\text { community engagement, lack of } \\
\text { marketing channels); }\end{array}$ & $\begin{array}{l}\text { Challenges in workers' welfare due to } \\
\text { incomplete institutional } \\
\text { arrangements; } \\
\text { Forced malpractice for survival due to } \\
\text { negative influences in the chain, such } \\
\text { as overstocking and illegal imports; }\end{array}$ \\
\hline $\begin{array}{l}\text { Environmental } \\
\text { capabilities }\end{array}$ & $\begin{array}{l}\text { Environmentally friendly } \\
\text { due to energy saving, less } \\
\text { packaging, and less } \\
\text { processing. }\end{array}$ & $\begin{array}{l}\text { Limited effects in environmental } \\
\text { protection due to a focus on isolated } \\
\text { opinions. }\end{array}$ & $\begin{array}{c}\text { Potential in reusing resources for } \\
\text { waste control, } \\
\text { Deficiency in tackling } \\
\text { agro-environment degradation, } \\
\text { increasing potential food safety risks. }\end{array}$ \\
\hline
\end{tabular}

The three types of rice SC have demonstrated capabilities, i.e., chain production, adaption, and innovation capabilities [31] to achieve sustainability goals [39]. 


\subsubsection{Farmer-Led Supply Chains}

There are two types of rice SCs led by farmers (see Table 1). In one type of rice chain, a single farmer manages a whole SC process from the production to the processing in his own mill, and the marketing to other villagers and restaurants. In the other type of rice SC, farmers acted as brokers to collect rice from individual farmers and suppled it either to mills or to Sino-grain. Both types of farmer-led rice SCs played a role in mobilizing household-level resources for high quality and low price food products, and improving household lifestyle and livelihoods. Relationships with farm households, mills, and where applicable, consumers, are important in farmer-led SCs. The farmers who owned mills reported that they contributed to increased food safety, the maintenance of indigenous knowledge in rice farming and processing, the strengthening of social networks, and community well-being. They said that their rice was the product of an environmentally friendly chain with fewer logistics and less packaging. Meanwhile, they are concerned more about natural nutrition without excessive processing. The farmer-led rice SCs argued that modern mills would polish the rice several times for glossiness, but they decide the level of processing based on rules to largely retain the nutritional quality of rice. Although the farmer-led rice SCs have diverse economic, social, and environmental sustainability capacities (see Table 2), their potential is restricted due to limited access to government investments in farming facilities and funds for continued improvements for their mills.

In the second type of farmer-led rice SC, the brokers reported that they provided a supporting role in helping some households without transportation to sell paddy rice easily, and also increased the efficiency of product flow through the chain. However, local farmers and key informants tended to report the negative side of "guanxi" (personal relationships) with such brokers. As Sino-grain and its branches gained profits or earnings based on the scale of procurement, each branch offered initiatives to expand the procurement. To improve efficiency and effectiveness, the branches of Sino-grain preferred rice brokers with large sales rather than household farmers as suppliers. Such rice brokers argued, and some farmers confirmed, that they reduced the transactional costs in facilities, labor, and accounting, and the repeated transactions and interactions increased the trust and relationships between brokers and Sino-grain. Furthermore, key informants reported some "proactive" brokers were likely to look for rent-seeking opportunities, such as bribery, to save their time and compete with farmers and other brokers. These factors contributed to the exclusion of small-scale farmers. Some farmers reported that they chose to use brokers because they had higher transaction costs than the brokers, greater price uncertainties due to the quality standards and hence price they could achieve for their rice, longer waiting time for the transaction, and emotional hurt or language abuse when in direct communication with Sino-grain. The downside of broker connections in rice SCs also posed challenges to the reputation of Sino-grain. Farmers expressed a hatred towards Sino-grain's procurement system, and to avoid Sino-grain, they were prepared to sacrifice some price by selling paddy rice directly to collectors. This also saved them time for off-farm work, and protected their dignity. Meanwhile, however, they accused brokers of having no consideration for farmers' well-being.

\subsubsection{Co-Op-Led Supply Chain}

There was one co-op-led SC in QF village, but this rice SC collapsed when its mill was closed. The formation of the co-op was based purposively on social networks to organize village committee members and those wealthy actors in the village with investment ability. The co-op-led rice SC had attracted collaboration between those with substantial capital and those who had skills to manage the government requirements, but it had difficulties translating the collaborative business operations into economic capabilities. Some respondents reported that the mill run by the co-op had operated for only three years, through government subsidies, and then failed because it had difficulties in surviving amid market fluctuations and the fierce competition. Another informant linked the failure of the co-op mill with the lack of clear goals and visioning, as the co-op members had more incentive to take advantage of government subsidies than to make entrepreneurial efforts, and to gain part time employment than to contribute to collective affairs. The low profits further decreased their interests 
in making entrepreneurial initiatives in the co-op. Similar information was received about co-ops in other villages.

The co-op members in QF village reported the rice SC contributed more to the SC than to building community connections. Thus, it did little for social capabilities. The co-op members interviewed stressed that the co-op focused on relationships with powerful people (those with substantial capital and those who had business skills), not ordinary ones. Meanwhile, villagers in QF village reported that the co-op members ignored relationships with village members. Local villagers, for their part, reported their indifference to the village-based co-op, as they believed the co-op worked for a few village committee members rather than distributing benefits across the village.

In terms of environmental sustainability, the co-op mill in QF village had partially stressed the contribution of time and labor-saving drying machines in controlling paddy rice waste. The members in the co-op argued that the aging rice producers and women lacked physical strength for traditional harvesting and drying. Increased opportunity costs of four days drying in the sunshine reduced farmers' enthusiasm for traditional drying. In addition, many rice brokers had contracted with the rural households for harvesting, and their increased workload demanded large-scale drying machines. The government's subsidies for drying machines and concessions for electricity fees had further accelerated agricultural modernization.

However, the co-op-led rice SC had never calculated the carbon emissions in adopting the mechanical drying process. Based on isolated opinions and cost-benefit reasoning, the co-op mill also ignored the function of culture against abandoning the traditional drying. Local government officers reported that the majority of people who had migrated to the city would come home for harvesting during the public holidays, and the men would play a key role by drying paddy rice for storage. The collective action in planting and harvesting among rice farming households was part of the lifestyle of celebration and rest.

\subsubsection{SME-Led Supply Chains}

Over a long period, sometimes decades, of development, some former farmer-led chains grew into SMEs with advanced technical investments in milling equipment. There are seven SME-led chains in the nearby township through which farmers from QF and $\mathrm{XH}$ villages can sell their paddy rice, but none specifically in QF or XH villages. The SME-led rice SCs linked economic capabilities with operational flexibility in volume and delivery, high product quality, and responsiveness to buyers' demands. Two informants reported that the competitiveness of SME-led rice SCs was sustained by many factors, including the local product advantages, accumulated knowledge, and experience in paddy rice quality grading, collaborative behaviors, and trustworthiness. One rice mill reported that mills and farmers engaged in a revenue sharing contract based on shared value and mutual trust. In this mode, farmers provide credit to rice mills, and the mill will pay the highest market price to farmers. The financial support and credit in local areas helps the mills overcome temporary capital shortages and allows their development of good processing facilities. Meanwhile, rice farmers are likely to gain a higher price to increase their income, and support from the mills if they are in trouble. These helpful actions improve the reputation of the mill and the community members trust it more. Farmers' social networks and word of mouth help to attract more suppliers from longer distances. Hence, trust, interdependence, and cooperative norms in their interactions contribute to a viable local pattern of economic development in SME-led rice chains.

Respondents also reported that changing local conditions pose three potential threats for the SME-led mills' economic sustainability. The owners of mills reported that increasing labor costs, the shortage of young labor, and food safety issues related to contamination by heavy metals increased the mills' difficulties and operational costs. One mill owner also explained the burden of close relationships in the rural area. In order to meet the social norms favoring specific suppliers or buyers with close personal relationships, the SMEs sometimes are forced to accept a partial loss, such as paying the maximum price for low grade paddy rice. 
The SME-led rice SCs reported that the top-down governance structure related to Sino-grain created mixed outcomes for their economic sustainability. SME respondents reported that Sino-grain's strong capabilities in paddy rice storage and logistics supports the SME's development to some extent. SMEs can treat Sino-grain as a storage service rather than building and staffing their own warehouses, reducing their production costs. Further, some mills with specific "guanxi" assets earned rents if supplying warehouses to Sino-grain, and also avoided the transport cost and ensured a stable supply of paddy rice if buying the paddy rice stored in their own warehouses. Meanwhile, some SMEs reported Sino-grain's monopoly role in controlling the flow of paddy rice increases the market dependence or vulnerability of the SME-led rice processing industry. In temporary shortages of freshly harvested paddy rice, SMEs have to pay a higher price to source rice from Sino-grain, and these higher payments for the paddy rice squeeze the mills' profits. Additionally, due to Sino-grain's commitment to protect rice farmers' income, the SMEs are forced to match the minimum price for freshly harvested paddy rice offered by Sino-grain when the market prices are lower. Further, China's paddy rice price has remained above the international market price for several years, and the distorted market signals encourage illegal imports of rice. Agricultural imports remained flat until the 2000s, but began to rise dramatically by the 2010s, and China has become a net importer of rice $[40,41]$. The imports make it difficult to rotate the reserves of paddy rice in Sino-grain, which causes further grain waste in the whole industry due to the perishable nature of paddy rice and the high levels of stock.

The SME-led rice SCs reported their social capabilities, including good relations with employees, local development, and fairness of marketing. Workers interviewed in one of the mills made positive comments about their personal well-being and sense of belonging in this work. They reported that having this off-farm job opportunity within walking distance of home made it easier to take care of their families and participate in their supportive social networks. However, buying commercial insurance for workers was a problem for the mills due to the nature of informal (or private) business. The mills have to pay a much higher price to buy group insurance for workers who are over sixty years old, on whom they depend increasingly with the shortage of younger laborers in the rice industry.

The SME-led rice SCs reported that they have encouraged the upgrading of the local rice industry, which promotes the development, diversification, and innovation of related sectors. According to several respondents, rice logistics services, farming equipment shops, and other agribusinesses like chemical and fertilizer shops, pre-harvesting, and harvesting extension service have become established around the SME-led rice SCs.

Meanwhile, SMEs reported that intersection of Sino-grain's governance and SMEs' practices resulted in negative social outcomes in rural areas. Respondents reported that SMEs were likely to source low quality paddy rice from Sino-grain. There are three reasons for low quality of rice. First, some branches of Sino-grain purposely buy stale grain and rename it as fresh rice to make illegal profits. Second, slack supervision leads to the sourcing of low-quality rice from buyers. Third, inappropriate stock management causes deterioration in rice quality due to lack of facilities or supervision. Some branches of Sino-grain were alleged to shift risks by selling inferior paddy rice to the local mills. However, they are unlikely to employ illegal practices of adulteration to survive in the wholesale market, where the government has imposed strict legislation and transparent inspection. For profit and survival, SME-led mills will sell rice with lower nutrition to less-aware township-based retailers and low-income consumers in rural and peri-urban areas, where levels of government inspection are low.

Mill managers in SME-led rice SCs reported that several factors are important for their capacities to reduce food waste in the chain. Proper procurement management helps to prevent deterioration and loss (e.g., eating by mice, birds). Technological innovation, especially reusing by-products of paddy rice, helps to reduce waste. Despite the potential of these measures, two respondents indicated the SME mills lacked the capital to obtain appropriate processing equipment. Meanwhile, key informants criticized the food waste caused by the overstocking of paddy rice in Sino-grain. The SME-led rice SCs reported that the food waste in the procurement process (due to the perishable nature of rice) poses 
great environmental and economic challenges, and it has limited effects in improving a mill's food saving performance.

\subsection{Interactions Between Rural Communities and Agri-Food Supply Chains}

The interactions between community capital assets in QF and $\mathrm{XH}$ villages and the sustainability capabilities in the three types of rice SC indicates the convergence of interests, and possible mutual benefits. This section explains the vertical and horizontal interactions between rice farming communities and rice SCs (Table 3).

Table 3. The Interactions between Rural Communities and Rice Supply Chains.

\begin{tabular}{ll}
\hline \multicolumn{1}{c}{ Supply Chains' Influences on Communities } & \multicolumn{1}{c}{ Communities' Influences on Supply Chains } \\
\hline $\begin{array}{l}\text { Increased price for the local villagers due to the } \\
\text { competition for high quality paddy rice supply }\end{array}$ & $\begin{array}{l}\text { The effectiveness of household and village-based } \\
\text { agro-environment protection of soil and water impacts } \\
\text { food quality }\end{array}$ \\
\hline $\begin{array}{l}\text { Creation of multiple livelihood opportunities due to } \\
\text { the need for labor, transport, storage, and marketing }\end{array}$ & $\begin{array}{l}\text { Enabling institutions, such as the provision of credit and } \\
\text { accumulated trust, ensure the chain level operations }\end{array}$ \\
\hline $\begin{array}{l}\text { Rice farming culture and social identity linked with } \\
\text { external interactions, such as rural-urban integration } \\
\text { and the global rice market }\end{array}$ & $\begin{array}{l}\text { Cross-sector collaboration in the community (such as } \\
\text { credit) impacts the rice industrial capability. }\end{array}$ \\
\hline
\end{tabular}

In vertical terms, the effectiveness of household and village-based protection of soil and water impacts food quality in the rice chains. Meanwhile, the increased value from an improved rice chain is likely to flow to rural households and villages through a higher market price for their paddy rice. In addition, an enabling community institutional structure, such as accumulated trust and credit, influences paddy rice supply, and cross-sector collaboration in the village supports chain level operation. This process also creates multiple livelihood opportunities in villages due to the need for laborers, transport, storage, and marketing. These interactions among chain level operations in villages affect the competence of the local rice industry. As the rice farming community develops further, it can become a more dynamic rural place, and more able to compete in the global rice market. Hence, both chains and villages can fulfil their potentials through working together.

Besides the mutually supportive relationships between rice SCs and rural communities, the interconnected chains and villages are also embedded in a structure of broader relationships that shape their interactions. As shown in Figure 3, the government plays a leading role to set an agenda to solve the "deficits" and "problems" in China's rice SC networks, for the public benefit. Village committees and agribusinesses, including Sino-grain, SME-led, and other larger rice SCs, are closely connected with the government. The SCs are regarded as supportive actors to help government-led development in rural communities and the rice industry. Meanwhile, the majority of rice farming households, some of which are also engaged as farmer brokers, rice millers, and co-op members, play a relatively reactive role in their specific groups. They strive to create individual strategies to adapt to the pressures they face, but are not well organized to pursue shared goals.

Under the influence of changing rice SCs over the last 20 years, the villages have turned from being closed villages under self-governance by village committees and rural households, to more dynamic places with blurred boundaries, as external and new social institutions, such as the government, migrant rural households, agribusinesses, and co-ops, are now involved and help to reshape aspects of the two case villages. Figure 3 illustrates these blurred boundaries. Besides the existing rural households and village committees, QF village was formally connected with the government through programs in building farming facilities and protecting the agro-environment, and funding the failed community-based co-op. XH village also connected with government through programs in building roads and farming facilities, but it had no formal connections with specific economic organizations. Meanwhile, it had informal connections with migrant rural households who rented land from village 
households. In summary, Figure 3 shows the communities have connections with many actors, giving them multiple opportunities for further development.

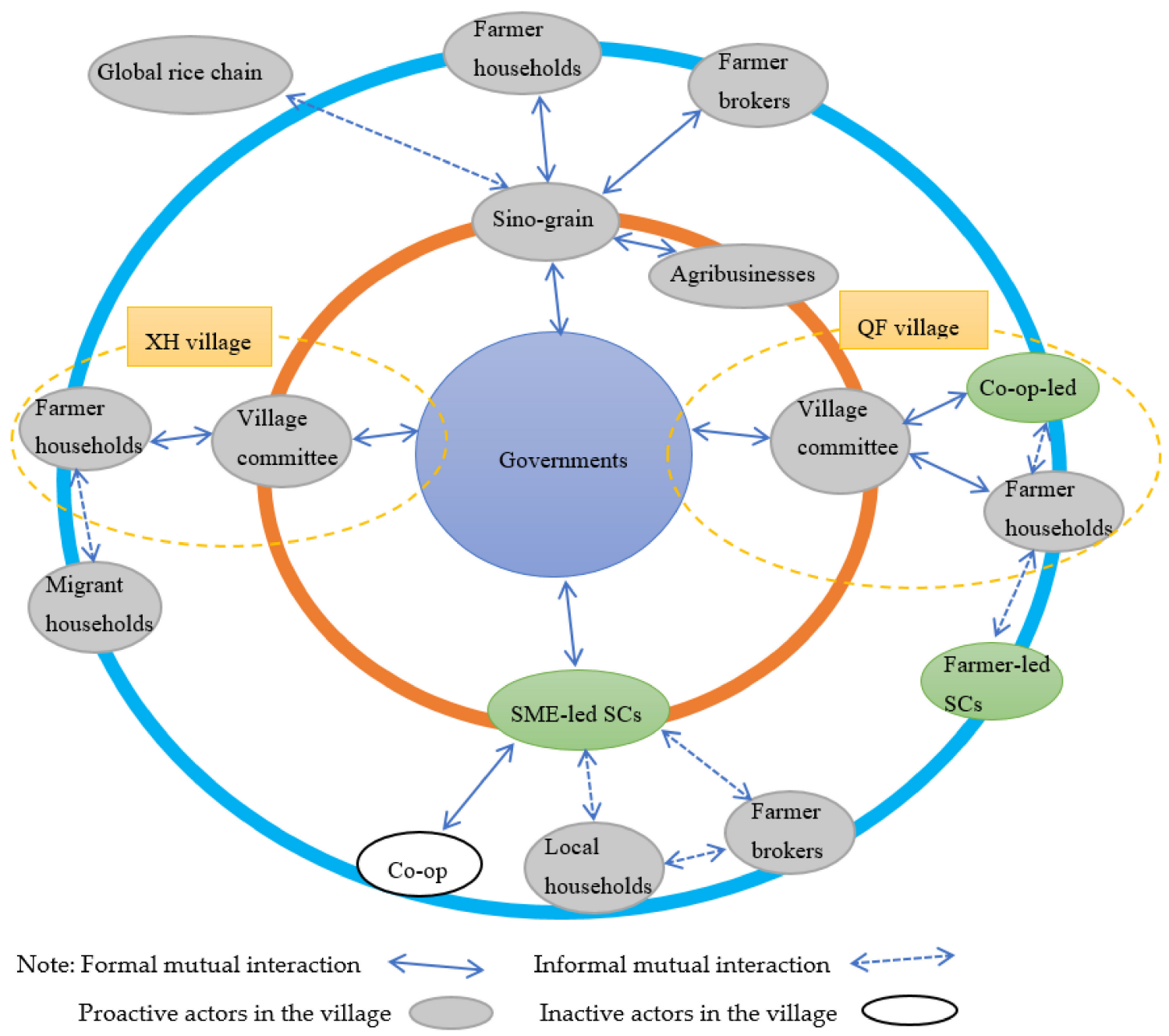

Figure 3. The Interactions of Rice Supply Chains and Villages.

\section{Discussion}

The SC-community interactions in central China have implications for sustainability from both a community perspective and a SC perspective. From a community perspective, the results suggest three desirable SCR pathways for community development. Firstly, a broad view of community, involving interconnected actors across and outside the personal networks and villages, is needed. The study results show that a narrow view of place-based community, ignoring these external linkages, may fail to leverage village level investments in natural, physical, financial capitals, and individual social relationships that could support further village development. This insight is aligned with the interactional view of community [42,43] and community development [44]. Secondly, the three types of SC are connected with different levels within a rural community (household level, village level, and areas beyond the villages), while rural community development requires coordination across all these levels of community. Thirdly, rice SCs and rural communities interact vertically and horizontally in terms of social, economic, and environmental issues. These interconnections offer government and community leaders opportunities to improve the pool of capital assets in villages and the sustainability capabilities in agri-food SCs. Especially, rice SC-rural village interactions not only happen in the obvious product-based network, but also in the deep socio-cultural network involved in 
rice activities $[3,45]$. This suggests that SCR needs to be built in explicit ways that focus on connections between villages and chains. The efforts towards SCR will not only expand chain level benefits and community well-being, but also create innovative governance mechanisms in agri-food systems.

Although network theories have expanded in SC research [46,47], SC research overwhelmingly ignores the community literature in regards to a network [33,48]. Existing chain level practices also lack community network thinking that would be useful to promote chain level performance $[5,12]$. Most practices focus on the development of an individual chain, and concern supplier relationship managements within a specific chain [49]. Little research considers the multiple connections across chains and communities or engages with their wider scope to create shared opportunities. Current research also fails to bridge the chains-communities divide and bring them together for collective benefits.

The SC-community interactions reveal the significance of community network thinking to inspire new ways for chain level sustainability. In this case, both agri-food SCs and villages are essential to development in the SC network. This contrasts with development agendas that give priority to the interests of some global agri-food SCs and some activities within chains [50] while suppressing the interests of farmer-led SCs and community development. For sustainability purposes, the divisions between modernized rice SCs and farmer-led rice SCs, as well as between well-developed and less-developed villages, are problematic. The SCs and communities in different development situations may have multiple connections. Effective SCR interventions and practices must acknowledge the nature of these interconnections for transformations [18,51].

Thinking in terms of the "community network" also provides an alternative perspective to promote development of SCs. The findings of this study reveal that the practices and benefits in the different types of SC are affected by the community capitals, especially at the specific level of community (household, village, and regions) they interact with. This is an additional dimension of the idea of a support SC proposed by Carter et al. [13]. Rather than a support structure for sustainability in individual chains, the networked structure offers a common support system, which creates sustainability for both chains and villages. The common structure envisaged here offers more realistic and practical implications for SCR. This perceives SCR not so much as a structural intervention to solve conflicts [52], or simple responses to community demands [7], but as a gradual social process to drive potentially beneficial interactions among actors, chains, and the network of chains. Thus, SCs need to extend their awareness of community to bring actors together for shared benefits. Chain level sustainability needs the management of the network of chains and communities, rather than the individual chains or communities. This perspective enriches our understanding of how to create truly sustainable SCs, as proposed by Pagell and Shevchenko [20], and Choi and Kim [35].

This study has its own limitations. Due to the short-term and necessarily limited scope of research, it could not hope to reveal every aspect of interactions between SCs and communities. For instance, the interactions between global rice SCs and rural communities are not attempted in this study. Meanwhile, we have studied a specific industry in China as an example. Due to the limited availability of empirical studies in other industries or countries, the generality of the study to other industries and other regions requires further study. Comparative research is needed in different industries, and in regions under different economic development conditions.

Collaboration across chains, or across chains and villages, is an under-studied field in chain level sustainability [12]. Integrated and innovative decision-making has potential to reduce the risk of policy fragmentation [53]. Future research and practices can embed this broader community structure view to promote the development SCs. Moreover, our research enriches the knowledge on how to build sustainable SCs [14] and communities, by linking SCs with the concept of community. However, it does not ease the complexity of achieving sustainability in the networks of chains and communities. Future research needs to examine the processes to integrate knowledge and practices to achieve sustainable outcomes [12]. It would be useful for future research to examine the interactions between SCs and rural communities, by qualitative, quantitative, and participatory methods. 


\section{Conclusions}

This paper uses SCR as a new philosophy to seek sustainability in a network of rice SCs and communities in China, beyond specific chains and actors. A focus on SC-community interactions offers a holistic perspective and integrated methods to examine SCR issues in China's regional rice industry. This study concludes that the rice SCs in the study area contribute to diverse community capitals but lead to a fragmented community structure in rice farming villages (research question 1). Further, a high level of community sustainability needs collective efforts from farmer-led, co-op-led, and SME-led rice SCs, as these chains are connected with well-being at the different levels of community: Households, villages, and areas beyond the villages, respectively (research question 2). Thus, the enabling elements that bring together diverse chains and villages and encourage their mutually supportive relationships will benefit rural community development (research question 3).

No agri-food SC or community in a locality or a region can claim to be immune from their mutual influence. A relatively narrow approach to SCR is not sufficient to tackle emerging challenges or realize opportunities for communities, or SCs. Our proposed perspective on SCR engages with chain capabilities and community capitals to understand interactions and hence mutual influences between agri-food SCs and rural communities. The findings reveal that there are many misalignments between sustainability-related intentions and real achievements in Wuhan. Collaborations across chains and focus on the SC-community nexus offer the best possible mutual benefits. Both chains and communities need to switch from individualistic patterns of behavior towards collective efforts offering greater potential for sustainability. The building of a collaborative, innovative, and inclusive community in such a network influences community prosperity, which also provides roots for a more sustainable SC.

Author Contributions: Conceptualization, L.L., H.R., and A.A.; methodology, L.L. and H.R.; formal analysis, L.L.; writing-original draft preparation, L.L.; writing-review and editing, H.R.; supervision, H.R. and A.A.; project administration, L.L.; funding acquisition, L.L. and H.R. All authors have read and agreed to the published version of the manuscript.

Funding: This research was funded by China Scholarship Council, grant number 201306770028, and the School of Agriculture and Food Sciences, The University of Queensland.

Acknowledgments: This work was part of a PhD research carried out between 2013 and 2017. We are grateful to Jim Cavaye for his supervision and constructive suggestions in preparing the research. We appreciate the funding from Global Justice Index Program in Institute for Advanced Study in Social Sciences at Fudan University for the writing stage.

Conflicts of Interest: The authors declare no conflict of interest. The funders had no role in the design of the study; in the collection, analyses, or interpretation of data; in the writing of the manuscript, or in the decision to publish the results.

\section{References}

1. Hall, J.; Matos, S. Incorporating impoverished communities in sustainable supply chains. Int. J. Phys. Distrib. Logist. Manag. 2010, 40, 124-147. [CrossRef]

2. Klassen, R.D.; Vereecke, A. Social issues in supply chains: Capabilities link responsibility, risk (opportunity), and performance. Int. J. Prod. Econ. 2012, 140, 103-115. [CrossRef]

3. Wieland, A.; Handfield, R.B.; Durach, C.F. Mapping the Landscape of Future Research Themes in Supply Chain Management. J. Bus. Logist. 2016, 37, 205-212. [CrossRef]

4. Yawar, S.A.; Seuring, S. Management of social issues in supply chains: A literature review exploring social issues, actions and performance outcomes. J. Bus.Ethics 2017, 141, 621-643. [CrossRef]

5. Montabon, F.L.; Pagell, M.; Wu, Z. Making Sustainability Sustainable. J. Supply Chain Manag. 2016, 52, 11-27. [CrossRef]

6. Spence, L.; Bourlakis, M. The evolution from corporate social responsibility to supply chain responsibility: The case of Waitrose. Supply Chain Manag. Int. J. 2009, 14, 291-302. [CrossRef]

7. Stoian, D.; Donovan, J.; Fisk, J.; Muldoon, M.F. Value chain development for rural poverty reduction: A reality check and a warning. Enterp. Dev. Microfinanc. 2012, 23, 54-60. [CrossRef]

8. Porter, M.E.; Kramer, M.R. Creating shared value. Harv. Bus. Rev. 2011, 89, 62-77. 
9. Fearne, A.; Martinez, M.G.; Dent, B. Dimensions of sustainable value chains: Implications for value chain analysis. Supply Chain Manag. Int. J. 2012, 17, 575-581. [CrossRef]

10. Fold, N. Value Chain Dynamics, Settlement Trajectories and Regional Development. Reg. Stud. 2014, 48, 778-790. [CrossRef]

11. Vicol, M.; Fold, N.; Pritchard, B.; Neilson, J. Global production networks, regional development trajectories and smallholder livelihoods in the Global South. J. Econ. Geogr. 2018, 19, 973-993. [CrossRef]

12. Carter, C.R.; Kosmol, T.; Kaufmann, L. Toward a supply chain practice view. J. Supply Chain Manag. 2017, 53, 114-122. [CrossRef]

13. Carter, C.R.; Rogers, D.S.; Choi, T.Y. Toward the Theory of the Supply Chain. J. Supply Chain Manag. 2015, 51, 89-97. [CrossRef]

14. Donovan, J.; Poole, N. Asset building in response to value chain development: Lessons from taro producers in Nicaragua. Int J Agr Sustain. 2013, 11, 23-37. [CrossRef]

15. Bolwig, S.; Ponte, S.; Du Toit, A.; Riisgaard, L.; Halberg, N. Integrating Poverty and Environmental Concerns into Value-Chain Analysis: A Conceptual Framework. Dev. Policy Rev. 2010, 28, 173-194. [CrossRef]

16. Vicol, M.; Neilson, J.; Hartatri, D.F.S.; Cooper, P. Upgrading for whom? Relationship coffee, value chain interventions and rural development in Indonesia. World Dev. 2018, 110, 26-37. [CrossRef]

17. Neilson, J.; Pritchard, B. Value Chain Struggles: Institutions and Governance in the Plantation Districts of South India; Blackwell: Oxford, UK, 2009.

18. Smith, K.; Lawrence, G.; MacMahon, A.; Muller, J.; Brady, M. The resilience of long and short food chains: A case study of flooding in Queensland, Australia. Agric. Hum. Values 2016. [CrossRef]

19. Munro, N. 'Market justice' in China and Russia. J. Chin. Gov. 2018, 3, 307-330. [CrossRef]

20. Pagell, M.; Shevchenko, A. Why Research in Sustainable Supply Chain Management Should Have no Future. J. Supply Chain Manag. 2014, 50, 44-55. [CrossRef]

21. Green, G.P.; Haines, A. Asset Building E Community Development; Sage Publication: Thousand Oaks, CA, USA, 2011.

22. Donoghue, E.M.; Sturtevant, V.E. Social Science Constructs in Ecosystem Assessments: Revisiting Community Capacity and Community Resiliency. Soc. Nat. Resour. 2007, 20, 899-912. [CrossRef]

23. Emery, M.; Flora, C. Spiraling-Up: Mapping Community Transformation with Community Capitals Framework. Community Dev. 2006, 37, 19-35. [CrossRef]

24. Segnestam, L. Division of Capitals-What Role Does It Play for Gender-Differentiated Vulnerability to Drought in Nicaragua? Community Dev. 2009, 40, 154-176. [CrossRef]

25. Sen, A. Commodities and Capabilities; Oxford University Press: Oxford, UK, 1999.

26. Clapp, J.; Sen, A. Development as Freedom. Int. J. Can. J. Glob. Policy Anal. 1999, 55, 160. [CrossRef]

27. Robeyns, I. The Capability Approach: A theoretical survey. J. Hum. Dev. 2005, 6, 93-117. [CrossRef]

28. Bhattacharyya, J. Theorizing Community Development. J. Community Dev. Soc. 2004, 34, 5-34. [CrossRef]

29. Dale, A. Agency: Individual 'Fit' and sustainable community development. Community Dev. J. 2014, 49, 426-440. [CrossRef]

30. Van Tulder, R.; Van Wijk, J.; Kolk, A. From chain liability to chain responsibility. J. Bus. Ethics 2009, 85, 399-412. [CrossRef]

31. Möller, K.E.; Törrönen, P. Business suppliers' value creation potential: A capability-based analysis. Ind. Mark. Manag. 2003, 32, 109-118. [CrossRef]

32. Long, N. Development Sociology: Actor Perspectives; Routledge: London, UK, 2003.

33. Sharp, J.S. Locating the community field: A study of interorganizational network structure and capacity for community action. Rural Sociol. 2001, 66, 403-424. [CrossRef]

34. Bessant, K.C. The Interactional Community: Emergent Fields of Collective Agency. Sociol. Inq. 2012, 82, 628-645. [CrossRef]

35. Choi, T.Y.; Kim, Y. Structural embeddedness and supplier management: A network perspective. J. Supply Chain Manag. 2008, 44, 5-13. [CrossRef]

36. Reardon, T.; Chen, K.Z.; Minten, B.; Adriano, L. The Quiet Revolution in Staple Food Value Chains: Enter the Dragon; Asian Development Bank: Mandaluyong City, Philippines, 2012.

37. Yin, R.K. Case Study Research: Design and Methods; Sage Publications: London, UK, 2014.

38. Collins, R.; Dunne, A. A rapid supply chain appraisal approach for agribusiness development projects. Acta Hortic. 2008, 794, 73-80. [CrossRef] 
39. Forsman-Hugg, S.; Katajajuuri, J.-M.; Riipi, I.; Mäkelä, J.; Järvelä, K.; Timonen, P. Key CSR dimensions for the food chain. Br. Food J. 2013, 115, 30-47. [CrossRef]

40. Alexandratos, N.; Bruinsma, J. World Agriculture Towards 2030/2050: The 2012 Revision; ESA Working Paper Rome; FAO: Quebec City, QC, Canada, 2012.

41. Gale, F.; Hansen, J.; Jewison, M. China's Growing Demand for Agricultural Imports; U.S. Department of Agriculture, Economic Research Service: Washington, DC, USA, 2015.

42. Bradshaw, T.K. The Post-Place Community: Contributions to the Debate about the Definition of Community. Community Dev. 2008, 39, 5-16. [CrossRef]

43. Theodori, G.L. Constraints to the Development of Community. Community Dev. 2008, 39, 91-110. [CrossRef]

44. Bridger, J.C.; Alter, T.R. An Interactional Approach to Place-Based Rural Development. Community Dev. 2008, 39, 99-111. [CrossRef]

45. Beske, P.; Land, A.; Seuring, S. Sustainable supply chain management practices and dynamic capabilities in the food industry: A critical analysis of the literature. Int. J. Prod. Econ. 2014, 152, 131-143. [CrossRef]

46. Borgatti, S.P.; Li, X. On Social Network Analysis in a Supply Chain Context. J. Supply Chain Manag. 2009, 45, 5-22. [CrossRef]

47. Carnovale, S.; Yeniyurt, S.; Yeniyurt, S. The Role of Ego Network Structure in Facilitating Ego Network Innovations. J. Supply Chain Manag. 2015, 51, 22-46. [CrossRef]

48. Sharp, J.S.; Flora, J.L.; Killacky, J. Networks and Fields: Corporate Business Leader Involvement in Voluntary Organizations of a Large Nonmetropolitan City. J. Community Dev. Soc. 2003, 34, 36-56. [CrossRef]

49. Lambert, D.M.; Schwieterman, M.A. Supplier relationship management as a macro business process. Supply Chain Manag. Int. J. 2012, 17, 337-352. [CrossRef]

50. Blowfield, M.E.; Dolan, C. Fairtrade Facts and Fancies: What Kenyan Fairtrade Tea Tells us About Business' Role as Development Agent. J. Bus. Ethic 2010, 93, 143-162. [CrossRef]

51. Sonnino, R.; Marsden, T. Beyond the divide: Rethinking relationships between alternative and conventional food networks in Europe. J. Econ. Geogr. 2006, 6, 181-199. [CrossRef]

52. Banks, G.; Scheyvens, R.; McLennan, S.; Bebbington, A. Conceptualising corporate community development. Third World Q. 2016, 37, 1-19. [CrossRef]

53. Jarzabkowski, P.; Kaplan, S.; Seidl, D.; Whittington, R. On the risk of studying practices in isolation: Linking what, who, and how in strategy research. Strateg. Organ. 2016, 14, 248-259. [CrossRef] 